DE

M E D I C I N A

T R O P I C A L

$\mathrm{DE}$

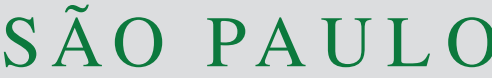

JOURNAL OF THE SÃO PAULO INSTITUTE OF TROPICAL MEDICINE

'Universidade do Estado do Rio de Janeiro, Rio de Janeiro, Rio de Janeiro, Brazil

2Universidade do Grande Rio, Rio de Janeiro, Rio de Janeiro, Brazil

${ }^{3}$ Centro Universitário Serra dos Órgãos, Teresópolis, Rio de Janeiro, Brazil

${ }^{4}$ Fundação Oswaldo Cruz, Escola Nacional de Saúde Pública, Rio de Janeiro, Rio de Janeiro, Brazil

Correspondence to: Abilene do Nascimento Gouvêa Universidade do Estado do Rio de Janeiro, Av. Professor Manoel de Abreu, 500, Vila Isabel, CEP 20550-170, Rio de Janeiro, RJ, Brazil

Tel: +55 $212868-8451$

E-mail: abilenegouvea@gmail.com

Received: 12 June 2020

Accepted: 25 August 2020

\section{Vertical transmission of HIV from 2007 to 2018 in a reference university hospital in Rio de Janeiro}

\author{
Abilene do Nascimento Gouvêa ${ }^{(1)}$, Alexandre José B. Trajano ${ }^{(1)}$ 1,2 , Denise L. \\ M. Monteiro 1,3, Nádia Cristina P. Rodrigues ${ }^{1,4}$, Julie Teixeira da Costa ${ }^{\circledR}$, \\ Mateus Benac Cavalcante ${ }^{(1)}$, Daniela Fortunato Auar ${ }^{(1)}$, Erika Ferraz de \\ Gouvea ${ }^{\circledR}$, Stella Regina Taquette ${ }^{\circledR}$
}

\section{ABSTRACT}

The aim of the study was to assess the factors associated with mother-to-child transmission (MTCT) of HIV. The study design is a retrospective cohort. The population consisted of 323 HIV-positive mothers and their newborns, attended at the Perinatal Nucleus/HUPE-UERJ, municipality of Rio de Janeiro, in the period of 2007-2018. The average age of mothers was 27 years (14-44), with $12.7 \%$ (41) of adolescents. The majority (66.8\%) knew they were infected during pregnancy: $39.4 \%$ in the current pregnancy and $27.4 \%$ in a previous pregnancy. The incidence of MTCT was $2.7 \%$ in 2007-2009, $1 \%$ in 2010-2015 and 0 in 2016-2018. The viral load in the $3^{\text {rd }}$ trimester of pregnancy was $>1.000$ copies $/ \mathrm{mL}$ or unknown in all mothers with positive newborns and in $19 \%$ (42/221) of mothers with negative newborns ( $p=0.003)$. The duration of antiretroviral use was $>4$ weeks in $92.3 \%(264 / 286)$ of mothers with HIV-negative newborns and in 2 in the HIV-positive group $(\mathrm{p}=0.004)$. One of the 4 infected newborns and 2 of the negative ones did not use oral zidovudine $(\mathrm{p}=0.04)$. There was no association between amniorrhexis and MTCT $(\mathrm{p}=0.99)$, with the Apgar score in the $5^{\text {th }}$ minute of life $(p=0.96)$, with marital status $(p=0.54)$, ethnicity $(p=0.65)$, adolescence $(\mathrm{p}=0.42)$, mode of delivery $(\mathrm{p}=0.99)$, beginning of prenatal care $(\mathrm{p}=0.44)$ or with maternal comorbidities $(\mathrm{p}=0.48)$. The conclusion of the study points out that the main factors associated with MTCT are the elevated maternal viral load in the $3^{\text {rd }}$ trimester, the time of use of ART and the non-administration of zidovudine for the newborns.

KEYWORDS: Vertical infectious disease transmission. HIV. Pregnancy. Incidence.

\section{INTRODUCTION}

In Brazil, the frequency of HIV infection among the female population of reproductive age has increased. The first case of MTCT of HIV was described in 1982, 18 months after the first diagnoses of the disease in adults. Most pediatric infections are acquired through MTCT that can occur during pregnancy, childbirth or breastfeeding ${ }^{1}$.

Preventing MTCT and ensuring the survival and well-being of women with the infection contribute directly to achieving one of the Sustainable Development Goals ${ }^{2}$. Although HIV infection is in the process of stabilization, it still presents high transmission rates, especially in women ${ }^{3}$.

Currently, most diagnoses of infection in the female population are made by antiHIV serological screening in prenatal care ${ }^{4}$. According to the Notifiable Diseases Information System (SINAN), from January 1980 to June 2019, 125,144 cases of 
HIV-infected pregnant women were reported, 8,600 cases in $2018,28 \%$ more than in 2007, when the number was 6.700 . In relation to HIV-infected children under 13 years old, 93.2\% had MTCT as the infection route ${ }^{5}$. Approximately $65 \%$ of MTCT cases occur during labor and the remaining cases during pregnancy, especially in the last few weeks. There is an additional risk of $7 \%$ to $22 \%$ in each exposure (feeding) due to breastfeeding 6 .

The knowledge of the HIV infection from the mother to the child allowed the elaboration, in 1994, of the prophylactic intervention proposal known as Protocol 076 of the AIDS Clinical Trial Group (PACTG 076), which contributed to the $67.5 \%$ reduction in the rate of MTCT. Initially, it consisted of the prescription of chemoprophylaxis with zidovudine (ZDV) during pregnancy and the suppression of breastfeeding ${ }^{8}$. In line with new epidemiological studies, other antiretrovirals in addition to ZDV were included, making up the combined antiretroviral therapy (ART) that drastically reduced the maternal viral load of HIV and, consequently, the vertical transmission ${ }^{9}$. Since the patients were enrolled in the study, three new protocols have been changed by the Ministry of Health of Brazil in 2007, 2010 and 2015. In 2007, ART with three drugs was recommended for all pregnant women, although those with a CD4 lymphocyte count above 200 cells $/ \mathrm{mm}^{3}$ and a viral load below 1000 copies were allowed to use ZDV monotherapy ${ }^{10}$. After 2010, monotherapy with ZDV was no longer allowed and triple therapy should be prescribed for all pregnant women after the $14^{\text {th }}$ week and pregnancy ${ }^{4}$.

Currently, it is believed that the risk of MTCT is related to the following factors: high maternal viral load (VL), failure to use adequate ART, maternal complications/ comorbidities, rupture of ovular membranes for more than four hours before birth and failure to perform cesarean section when the VL is $>1000$ copies $/ \mathrm{mL}$, after 34 weeks of gestation ${ }^{11,12}$.

Nevirapine prescription is indicated for newborns (NB) whose mothers: did not have at least 4 weeks of ART prior to delivery or have poorly adhered to its use, presented in the last trimester of pregnancy VL $>1000$ copies/ $\mathrm{mL}$ or unknown $\mathrm{VL}$, had sexually transmitted infections (especially syphilis) and, who were tested for HIV only at the time of delivery ${ }^{13}$.

According to national guidelines, NB exposed to HIV should not be breastfed. Cross-breastfeeding (breastfeeding the child by another nursing mother) and the use of human milk with home pasteurization are also contraindicated ${ }^{13}$.

The rate of MTCT, without any intervention, is around $20 \%$ but with the combined use of all recommended actions, this number can drop to $1 \%{ }^{12}$. Even with the availability of this set of measures, the rate of MTCT in Brazil remains high. In this sense, the Ministry of Health recommended the establishment of Investigation Committees for the Prevention of Vertical Transmission in the municipalities, States and/or regions of health, and, to enable the performance of these committees, a protocol for the investigation of cases ${ }^{12}$. In addition to reinforcing the guidelines of the Ministry of Health to reduce HIV infection rates, the systematic monitoring of indicators related to MTCT makes it possible to measure the effectiveness of interventions at the local level ${ }^{14}$.

This study aims to assess the prevalence of MTCT and factors associated with MTCT at the Perinatal Nucleus, Pedro Ernesto College Hospital, Rio de Janeiro State University, Rio de Janeiro (PN-HUPE/UERJ), Rio de Janeiro, Brazil, during the period of 2007 to 2018.

\section{METHODS}

This is a retrospective cohort study. It was carried out at PN-HUPE/UERJ, a public hospital located in the Northern area of the city of Rio de Janeiro, a reference for specialized care of high maternal-fetal risk diseases. The prenatal clinic receives HIV-positive women who have already being monitored at the hospital or were referred by the regulatory systems. The consultations take place at the Obstetrics, Infectious and Parasitic Diseases clinics. HIV-positive women hospitalized in labor may or may not have performed prenatal care at the unit. After delivery, NB are followed-up in a specialized outpatient clinic of Pediatrics for children vertically exposed to HIV. The study population consists of pregnant women with HIV and their newborns, who were born in the maternity hospital between 2007 and 2018. All HIV carriers who received birth assistance at NP-HUPE/UERJ and their NB were included, except for those women whose pregnancy outcomes were either abortion, intrauterine fetal death or stillborn. Data were collected from the medical records of pregnant women and $\mathrm{NB}$, from hospitalization and delivery summaries, from the medical/nursing visit book of obstetrics, pediatrics and the human milk bank of the NP-HUPE/UERJ, on the website of the HUPE laboratory and the State Health Department, on the HUPE epidemiology service, on the birth registration system and on the Neonatology database. During this period, all patients were monitored by the same infectious disease team.

The variables used were data on pregnancy, childbirth, the puerperium and the follow-up of the NB. Existing variables in the Live Birth Certificate were also used, since they are used by the Information System to build epidemiological indicators of the health area.

The defined variables were: 1) Response variable: 
occurrence of MTCT of HIV; 2) Explanatory variables: sociodemographic data (age, ethnicity, education, marital status and occupation), data related to pregnancy (number of pregnancies, time of diagnosis of HIV infection, start and time of use of ART during pregnancy, VL in the third trimester, prenatal care, gestational age at the beginning of prenatal care, number of prenatal consultations and maternal comorbidities), data related to childbirth (route of delivery, membrane integrity, use of intravenous ZDV during childbirth), data related to the NB (Apgar, weight, Ballard, early bath, aspiration of the airways, use of ZDV and nevirapine, type of feeding, VL result at 30 and 60 days and serology at 18 months), data related to the puerperium (lactation inhibition and method used).

Newborns were considered uninfected if they presented two VL below the detection limit (or below 5000 copies/ $\mathrm{mL}$ ), according to modifications established by the Ministry of Health, during the study period. Children with negative antibody testing after 18 months of life were also considered uninfected ${ }^{15-17}$.

According to the Brazilian Clinical Protocol and Therapeutic Guidelines (2019), created by the Ministry of Health, exposed newborns with a test result of $\leq 5000$ copies $/ \mathrm{mL}$, carried out two weeks after the interruption of antiretroviral prophylaxis, strongly suggests a false positive result, and the test should be repeated after four weeks. Two PCR results with values below the same limit ( 2 and 6 weeks after ending the antiretroviral prophylaxis) exclude the vertical transmission. Positive results should be repeated as soon as possible. HIV serology must be performed at 18 months of age for documenting the case. This recommendation was updated in the last guideline. In 2014, the exclusion of the infection was recommended if there were two viral load tests (quantitative PCR) below the detection limit. The first one at 30 days of age and a second round at 4 months of age. Results of $\leq 5000$ copies / $\mathrm{mL}$ should be evaluated as a false positive. The 2009 consensus diagnosed HIV negative infants if there were two viral load tests below the detection limit (values lower than 10,000 copies should be reassessed as false positives); considering the tests have intervals of two months between them, with at least one of them after the fourth month of life and HIV serology negative after 12 months ${ }^{15-17}$.

Adequate prophylactic measures were divided into: Stage 1- those adopted during pregnancy (ART and prenatal care); Stage 2- during delivery (venous ZDV and definition of the mode of delivery according to VL) and Stage 3- in the postpartum period (oral ZDV associated or not with nevirapine in the baby, lactation inhibition, type of feeding and procedures performed).
During the course of the study, some recommendations were reviewed by the Ministry of Health. Prophylactic measures were considered adequate when performed in accordance with the recommendations of the Ministry of Health in force during the period of pregnancy, childbirth and postpartum.

Data were statistically analyzed through proportions, means, standard deviations and medians. Missing data were excluded from the analysis. The rate of MTCT was calculated by the proportion of HIV-infected newborns among those born to HIV-positive mothers, expressed with a 95\% confidence interval. Maternal and NB characteristics and MTCT prophylactic measures from steps 1 to 3 were presented as the relationship between the total value (n) and the one found in HIV-positive NB, being compared between-positive and HIV-negative NB to assess the vertical transmission. Associations between MTCT and possible risk factors were tested using the $\chi^{2}$ test for categorical variables and the Student's $t$ test for continuous variables. The level of significance was established as a p-value $<0.05$. The data entry and statistical analysis process was carried out using the EPIINFO 3.5.2 Computer Program. This project was approved by the Research Ethics Committee of HUPE/UERJ, CAAE $\mathrm{N}^{\circ}$ 10523719.6.0000.5259.

\section{RESULTS}

The study population consisted of 323 pairs of HIV-positive mothers and their NB, after the exclusion of nine pregnant women who had abortions, intrauterine fetal death or stillbirths. The age of the pregnant women ranged between 14 and 44 years old with a mean age of $27.4 \pm 6.4$ years and median of 27 years. The adolescents represented $12.7 \%$ (41/323), $72.4 \%$ (234/323) were between 20 and 34 years old and $14.9 \%$ (48/323) of them were 35 years old or more. Black and of mixed ethnicity pregnant women represented $61 \%(192 / 315)$, education was less than 10 years of study in $50.5 \%$ (158/313), $47.3 \%$ were married or in a stable relationship (150/317), 53.6\% (155/289) did not work outside the home and 5.2\% (15/289) were students (Table 1). There was no association between marital status $(\mathrm{p}=0.54)$, ethnicity $(\mathrm{p}=0.65)$, education $(\mathrm{p}=0.32)$ and adolescence $(\mathrm{p}=0.42)$ with MTCT.

MTCT occurred in 4 of the 323 cases, one being a teenager mother and three aged between 20 and 34 years. The incidence of MTCT was $2.7 \%$ (2/73) in 2007-2009, $1 \%(2 / 197)$ in 2010-2015, and there was no MTCT between 2016 and 2018. MTCT was more frequent among married women ( 3 married and 1 single), as well as among those with less than 10 years of study (3/4). No variable related 
Table 1 - Sociodemographic characteristics of HIV-positive pregnant women attended at a reference maternity hospital in Rio de Janeiro, 2007-2018.

\begin{tabular}{|c|c|c|c|c|}
\hline Characteristic & Result & $\mathrm{N}$ & $\begin{array}{c}\text { Vertical transmission } \mathrm{n} \\
(\%)\end{array}$ & $p$-value \\
\hline Age (years) & $<20$ & 41 & $1(2.4)$ & 0.42 \\
\hline mean $=27.4 \pm 6.4$ & $\geq 20$ & 282 & $3(1.1)$ & \\
\hline \multirow{2}{*}{ Skin color } & white & 123 & $2(1.6)$ & 0.65 \\
\hline & black/of mixed ethnicity & 192 & $2(1.1)$ & \\
\hline \multirow{2}{*}{ Education (years) } & $<10$ & 158 & $3(1.9)$ & 0.32 \\
\hline & $\geq 10$ & 155 & $1(0.6)$ & \\
\hline \multirow{2}{*}{ Marital status } & united/married & 150 & $3(2)$ & 0.54 \\
\hline & other & 167 & $1(0.6)$ & \\
\hline \multirow{3}{*}{ Profession } & don't work & 155 & $2(1.3)$ & 0.99 \\
\hline & student & 15 & 0 & \\
\hline & work outside & 119 & $2(1.7)$ & \\
\hline
\end{tabular}

to sociodemographic characteristics was associated with MTCT (Table 1).

The moment of diagnosis occurred during pregnancy in $66.8 \%(185 / 277), 27.4 \%(76 / 277)$ in the previous pregnancy and $39.4 \%(109 / 277)$ in the current pregnancy. It was observed that 9 pregnant women were infected by vertical transmission, corresponding to young between 15 and 23 years old. It was observed that MTCT occurred exclusively among those who discovered seropositivity during pregnancy.

Regarding the number of pregnancies, $44.6 \%$ (144/323) were in the first or second pregnancy and $55.4 \%$ (179/323) referred from 3 to 17 pregnancies. There was no MTCT among the primiparous women. Maternal comorbidities were reported in $54.8 \%$ (149/272), but they were not associated with MTCT $(\mathrm{p}=0.48)$. In the group of HIV-positive NB (4), only one of the mothers had co-morbidities (hypertension and schizophrenia). In the HIV-negative NB group, 148 mothers had comorbidities: 64 of them had sexually transmitted infections (49 of which syphilis), 26 were hypertensive, 19 had urinary tract infections, 10 were diabetic, 9 had respiratory diseases ( 3 of which tuberculosis), 6 had heart diseases, 4 had neurological diseases, 4 had hematological diseases, 3 had neoplasms and 3 had autoimmune diseases. The first consultation was held in the $1^{\text {st }}$ trimester in $42 \%(126 / 300)$ and $72.9 \%$ (210/288) of the pregnant women had six or more prenatal consultations ( $\mathrm{p}=0.44$ and 0.11 , respectively).

ART was used during pregnancy in $93.8 \%$ (272/290), with $42.8 \%(99 / 231)$ starting in the $1^{\text {st }}$ trimester and $91.4 \%(265 / 290)$ using it for more than 4 weeks. One of the 4 mothers with infected NB and $5.9 \%$ of the other group $(17 / 286)$ did not use ART $(p=0.45)$. The duration of ART use > 4 weeks occurred in 92.3\% (264/286) of mothers with HIV-negative NB and in 1 of the 4 in the HIV-positive group ( $\mathrm{p}=0.004)$. Intravenous $\mathrm{ZDV}$ before delivery was administered to $90.4 \%$ (255/282) of women during childbirth. The indication for cesarean section by VL $>1000$ copies/mL or unknown did not occur in $2.2 \%$ $(5 / 224)$, because these pregnant women arrived at the maternity in advanced labor. There was an association only between the time of ART use and MTCT.

Among the cases that underwent amniorrhexis $\geq 4$ hours before delivery, 47 women, none in the group with an HIVpositive NB ( $\mathrm{p}=0.79)$.

The VL in the $3^{\text {rd }}$ trimester was $>1000$ copies $/ \mathrm{mL}$ or unknown in all mothers of positive NB and in 19\% (42/221) of mothers with negative NB, being associated with MTCT $(\mathrm{p}=0.003)$ (Table 2).

The prematurity rate was $11.4 \%(31 / 273)$, the Apgar score $<7$ in the $5^{\text {th }}$ minute was found in $1 \%(3 / 305)$ and the NB's weight was $<2.500 \mathrm{~g}$ in $19.1 \%$ (59/309). There was no association between prematurity $(\mathrm{p}=0.70)$, the Apgar score in the $5^{\text {th }}$ minute of life $(p=0.96)$ and the weight of HIV-positive and negative NB $(\mathrm{p}=0.43)$ with MTCT.

In relation to stage 3 , oral $\mathrm{ZDV}$ was administered to $98.9 \%(262 / 265)$ of NB. One of the infected NB and 2 of the negative NB did not use oral ZDV $(p=0.04)$. Oral ZDV was administered within 4 hours of life in $91.5 \%(227 / 248)$ of cases. Nevirapine was administered to $8.9 \%$ of NB (24/268), being indicated in 11 children whose mothers did not use ART during pregnancy or had poor adherence to ART and in $13 \mathrm{NB}$ whose maternal VL in the $3^{\text {rd }}$ trimester was $>1000$ copies/mL or the result was not available at the time of delivery. It is noteworthy that none of the 24 NB who used nevirapine became HIV-positive. There 
Table 2 - Characteristics of pregnancy and adoption of prophylactic VT measures in 323 HIV-positive mothers (stages 1 and 2) in a reference maternity hospital in Rio de Janeiro, 2007-2018.

\begin{tabular}{|c|c|c|c|c|}
\hline Characteristic & Result & $\mathrm{N}$ & $\begin{array}{c}\text { Vertical transmission } \\
\mathrm{n}(\%)\end{array}$ & $\mathrm{p}$-value \\
\hline \multirow{4}{*}{ Moment of diagnosis } & Out of pregnancy & 83 & 0 & 0.45 \\
\hline & Previous pregnancy & 76 & $3(3.9)$ & \\
\hline & Current pregnancy & 109 & $1(0.9)$ & \\
\hline & Vertical transmission & 9 & 0 & \\
\hline \multirow{2}{*}{ Number of pregnancies } & up to 2 pregnancies & 144 & $2(1.4)$ & 0.37 \\
\hline & from 3 to 17 pregnancies & 179 & $2(1.1)$ & \\
\hline \multirow{2}{*}{ Maternal comorbidities } & yes & 149 & $1(0.7)$ & 0.48 \\
\hline & no & 123 & $3(2.4)$ & \\
\hline \multirow{2}{*}{$\mathrm{N}^{\circ}$ of prenatal appointments } & 1 to 5 & 78 & $3(3.8)$ & 0.11 \\
\hline & 6 or more & 210 & $1(0.5)$ & \\
\hline \multirow{2}{*}{$1^{\text {st }}$ prenatal appointment } & $1^{\text {st }}$ quarter & 126 & $1(0.8)$ & 0.44 \\
\hline & 2nd-3rd quarter & 174 & $3(1.7)$ & \\
\hline \multirow{2}{*}{ ART during pregnancy } & yes & 272 & $3(1.1)$ & 0.45 \\
\hline & no & 18 & $1(5.5)$ & \\
\hline \multirow{2}{*}{ Beginning of ART } & $1^{\text {st }}$ quarter & 99 & 0 & 0.37 \\
\hline & $2^{\text {nd }}$ and $3^{\text {rd }}$ quarters & 132 & $3(2.3)$ & \\
\hline \multirow{2}{*}{ ART Time } & $\leq 4$ weeks & 25 & $3(12.0)$ & 0.004 \\
\hline & $>4$ weeks & 265 & $1(0.38)$ & \\
\hline \multirow{2}{*}{ Venous AZT before delivery } & yes & 255 & $4(1.6)$ & 0.99 \\
\hline & no & 27 & 0 & \\
\hline \multirow{2}{*}{ Mode of delivery } & vaginal & 89 & $1(1.1)$ & 0.99 \\
\hline & cesarean & 231 & $3(1.3)$ & \\
\hline \multirow{2}{*}{ Amniorrhexis } & $<4 \mathrm{~h}$ & 78 & 2 & 0.79 \\
\hline & $\geq 4 \mathrm{~h}$ & 47 & 0 & \\
\hline \multirow{2}{*}{ Viral load in the $3^{\text {rd }}$ quarter } & $<1000$ copies $/ \mathrm{mL}$ & 179 & 0 & 0.003 \\
\hline & $\geq 1000$ copies $/ \mathrm{mL}$ or unknown & 46 & $4(8.7)$ & \\
\hline
\end{tabular}

was no association between amniorrhexis and MTCT of HIV ( $\mathrm{p}=0.99$ ). Regarding the procedures in the NB, none showed an association with MTCT: 93\% (252/271) had an early bath, $49.6 \%$ (130/262) aspiration of the airways and $40 \%(111 / 277)$ had skin to skin contact. The method of inhibiting the lactation of puerperal women also showed no association with MTCT, being mechanical in 55\% $(152 / 276)$ of the cases and in 45\% (124/276) mechanical associated with the pharmacological method (Table 3 ).

\section{DISCUSSION}

MTCT in the Perinatal Nucleus HUPE-UERJ occurred in $2.7 \%$ in 2007-2009, 1\% in 2010-2015 and since 2016 there has been no other cases. This rate is in line with the World Health Organization (WHO) goals, in which, when correct measures are adopted, vertical transmission should be around $1 \%{ }^{12}$. When compared to other Brazilian studies, our rate was lower, since in a survey carried out in Petrolina (PE) and Juazeiro (BA), in Northeastern Brazil, the rate of MTCT was $8.6 \%^{18}$, in Amazonas it was $6.6 \%{ }^{19}$, in Rio Grande (RS) it was $3.8 \%$ and in Belo Horizonte (MG) it was $1.9 \%{ }^{21}$. A metanalysis carried out in Ethiopia estimated MTCT at $11.4 \%$.

Regarding sociodemographic variables, the median age of mothers was 27 years and was not associated with MTCT, agreeing with studies of Belo Horizonte (MG), Amazonas and Ethiopia ${ }^{19,21,22}$. A study in Israel described a similar result: the mean age of women who transmitted HIV was 27 years and the mean age was $26^{22}$.

In addition, color, marital status and education did not show association with MTCT. Studies carried out in the 
Table 3 - Characteristics of the newborns and adoption of VT prophylactic measures (step 3) in a reference maternity hospital in Rio de Janeiro, 2007-2018.

\begin{tabular}{|c|c|c|c|c|}
\hline Parameter & Result & $\mathrm{N}$ & $\begin{array}{c}\text { Vertical transmission } \\
\mathrm{n}(\%)\end{array}$ & $p$-value \\
\hline \multirow{2}{*}{ Ballard } & $<36 \mathrm{~s}$ & 31 & 0 & 0.70 \\
\hline & $\geq 36 \mathrm{~s}$ & 242 & $3(1.2)$ & \\
\hline \multirow{2}{*}{ APGAR $1^{\text {st }} \min$} & $<7$ & 29 & 0 & 0.67 \\
\hline & $\geq 7$ & 275 & $4(1.5)$ & \\
\hline \multirow{2}{*}{ APGAR $5^{\text {th }} \min$} & $<7$ & 3 & 0 & 0.96 \\
\hline & $\geq 7$ & 302 & $4(1.3)$ & \\
\hline \multirow{2}{*}{ NB weight } & $<2500 \mathrm{~g}$ & 59 & 0 & 0.43 \\
\hline & $\geq 2500 \mathrm{~g}$ & 250 & $4(1.6)$ & \\
\hline \multirow{2}{*}{ Use oral AZT } & yes & 262 & $3(1.1)$ & 0.04 \\
\hline & no & 3 & $1(33.3)$ & \\
\hline \multirow{2}{*}{$\begin{array}{l}\text { Number of hours of life to } \\
\text { use oral AZT }\end{array}$} & $\leq 4 \mathrm{~h}$ & 227 & $3(1.3)$ & 0.76 \\
\hline & $>4 \mathrm{~h}$ & 21 & 0 & \\
\hline \multirow{2}{*}{ Use of nepivarin } & yes & 24 & 0 & 0.68 \\
\hline & no & 244 & $4(1.6)$ & \\
\hline \multirow{2}{*}{ Early bath } & yes & 252 & $3(1.2)$ & 0.80 \\
\hline & no & 19 & 0 & \\
\hline \multirow{2}{*}{ Airway aspiration } & yes & 130 & $3(2.3)$ & 0.12 \\
\hline & no & 132 & 0 & \\
\hline \multirow{2}{*}{ Skin to skin contact } & yes & 111 & 0 & 0.21 \\
\hline & no & 166 & $3(1.8)$ & \\
\hline \multirow{2}{*}{ Lactation inhibition method } & mechanic & 152 & $2(1.3)$ & 0.99 \\
\hline & mechanical+pharmacological & 124 & $2(1.6)$ & \\
\hline \multirow[t]{2}{*}{ NB feeding } & formula & 308 & $4(1.3)$ & 0.99 \\
\hline & breast milk+formula & 3 & 0 & \\
\hline
\end{tabular}

Northeast found that the majority of HIV-positive pregnant women were of mixed ethnicity or black ${ }^{3,18}$. Since 2009 , AIDS cases are more prevalent in black and of mixed ethnicity women. According to the Ministry of Health, in 2018, women with mixed ethnicity concentrated $48 \%$ and black $13.7 \%$ of HIV-infected pregnant women in Brazil, which is in line with our results. The proportion of white pregnant women, even in a constant downward trend, was higher than that of mixed ethnicity women from 2000 to 2011, while the trend among of mixed ethnicity women grew and in 2012 when they became the majority of cases in the country ${ }^{7,12}$. These data indicate that it is essential to implement and maintain public policies for prevention as well as adequate and efficient assistance to the black population ${ }^{23,24}$.

In our study, the number of pregnant women with education $<10$ years was close to the group that studied 10 or more years. MTCT was more frequent (3/4) among mothers with less education, in agreement with a study in the Northeast ${ }^{18}$ that found $77.6 \%$ of schooling up to eight years and in Belo Horizonte $(\mathrm{MG})^{21}$ it was less than 8 years in $65.7 \%$.

Almost half of the pregnant women in our study were married/united and MTCT was more frequent in this group (3/4). Our results disagree with most studies. Cardoso et al. describe that younger, unmarried pregnant women or those who do not live with a partner are more exposed to HIV infection ${ }^{25}$. Studies in Zambia in 1998 and in Latin America in 2002 showed that unmarried women are more likely to have multiple sexual partners and that frequent casual encounters can increase the likelihood of having sex with an HIV-infected partner ${ }^{26,27}$.

It was found that more than half of the pregnant women did not have a paid employment, a data similar to that found in other Brazilian studies ${ }^{14}$, as well as in other countries with different cultures and economies, such as Vietnam ${ }^{28}$. The occupation also showed no association with MTCT. 
Our results reiterate the importance of using ART to prevent MTCT, as it was related to the time of use exceeding four weeks. MTCT occurred in 3 cases when the pregnant women used ART for a shorter period, a significant factor in this study $(\mathrm{p}=0.004)$. In Israel, after the implementation of ART in the national recommendations, there was a reduction in MTCT from $16.3 \%$ to $1.7 \%{ }^{29}$. At the national level, several authors have confirmed this association ${ }^{18,20,21}$. Although the MTCT has decreased over the study period, the authors cannot affirm whether there is a correlation, because the use of ARV was not available in all medical records.

All mothers of positive NB had VL in the $3^{\text {rd }}$ trimester $>1000$ copies $/ \mathrm{mL}$ or VL unknown, showing the important association between VL and MTCT ( $\mathrm{p}=0.003)$. This number may reflect only the fact that the patient did not have her test result at the time of delivery, despite having performed it. This situation improved a lot after the computerization of laboratory results in the SISGENO network (System and Information for Genotyping Exams), from 2016. Studies in Rio Grande (RS) and Belo Horizonte (MG) also confirmed the association between VL and MTCT ${ }^{20,21}$. Melo et al. ${ }^{21}$ showed that MTCT occurred in half of pregnancies in which the VL was $>1000$ copies $/ \mathrm{mL}(\mathrm{p}=0.02)$; Barbosa et al ${ }^{14}$ claimed that the lower the mother's VL, the lower the possibility of MTCT, with the aim of ART being to reduce these values. In that same study, there was a considerable deficit of data in relation to the VL examination, showing the difficulties of some health services in addressing and verifying viremia.

Maternal comorbidities did not show an association with MTCT, a fact corroborated by Melo et al. ${ }^{21}$.

Most diagnoses occurred during pregnancy (current or previous) and MTCT did not occur among those who learned of their seropositivity before pregnancy. This shows the importance of prenatal care as a means of screening for HIV, showing that it is an important moment of diagnosis. Endalamaw et $a .^{22}$ also showed that the MTCT rate was higher among mothers who knew their HIV seropositivity during pregnancy or after childbirth than among those who were previously aware.

It was observed that $72.9 \%$ had six or more prenatal consultations, following the recommendation of the Ministry of Health ${ }^{12}$. This number represents a greater engagement of pregnant women at the HUPE-UERJ Perinatal Nucleus and stronger link between patients and the health establishment when compared to a reference hospital in Alagoas, which came to present almost $10 \%$ of women in childbirth without any prenatal consultation ${ }^{30}$. A study from Goiania showed that most pregnant women had only 1 to 5 prenatal consultations ${ }^{14}$. This adherence may be associated with the performance of consultations of specialists in obstetrics, infectious diseases and pediatrics, as well as a multidisciplinary care in a single center.

The characteristics of the NB showed that the vast majority were born in good conditions, showing no association with MTCT. Melo et al. ${ }^{21}$, in Minas Gerais, also showed a similar result in the analysis of these variables.

Almost all NB used oral ZDV and, in most cases, it was administered up to 4 hours of life, in accordance with the recommendation of the Ministry of Health ${ }^{12}$. The use of oral ZDV by the NB had a statistically significant association with MTCT, which agrees with a study carried out in Alagoas, which showed that of four children infected by the virus, three did not receive prophylactic ZDV at delivery $^{30}$. A study carried out in Angola showed that the risk of MTCT was higher in NB who did not receive prophylaxis (32\%) compared to those who did $(7 \%)^{31}$. A metanalysis in Ethiopia revealed that NB exposed to HIV who did not receive prophylaxis and whose mothers did not receive ART during pregnancy were almost six times more likely to contract HIV infection ${ }^{22}$.

The administration of nevirapine within the protocol proposed by the Ministry of Health showed, in our study, that none of the 24 babies who used the substance became HIV-positive. A study in Ethiopia found that the chance of HIV infection in NB was 5.3 times higher among infants without nevirapine intervention compared to those who received this drug 32 .

Several procedures are recommended in the care of NB to avoid contact of maternal blood as much as possible. Clamp the umbilical cord immediately after birth; cleanse blood and secretions with compresses, immediately after birth; bathing in the delivery room; gently aspirate the airways; aspirate with oral tube, the gastric content of amniotic fluid and put the NB in physical contact with the mother as soon as possible, ensuring the mother-child bond $^{13}$. In our study, interventions in NB were not associated with MTCT, in agreement with the study by Arango-Ferreira et al..$^{33}$ in Colombia.

As for the lactation inhibition, the mechanical method was the most used and, secondly, the association of this method with the pharmacological method. Currently, the Ministry of Health guides the pharmacological method with the use of cabergoline to inhibit lactation, with breast wrapping being sed only when there are no pharmacological inhibitors $^{12}$. Et Moreno et al. ${ }^{34}$ suggest that bandaging as a process of inhibition of lactation is felt as a punishment and is painful. It is worth mentioning that, in our unit, the use of "gym top" to support the breasts is recommended as a mechanical method associated with the pharmacological one, enhancing the suppression of lactation. 
As limitations of the study, we pointed out flaws in recording data in the medical notes of viral load and TCD4 + lymphocyte count, the same observation reported by Barbosa et al. ${ }^{14}$ in Goias State. It is urgent that the health team becomes aware of the need to record the results of exams in the medical notes, especially the VL in the $34^{\text {th }}$ week of pregnancy, because the choice of delivery method is based on this information. Again, it is evident that the computerization of data has a fundamental role in the approach of the parturient, since childbirth does not always occur in the same place where the pregnant woman performed the prenatal care.

Another point of failure was the lack of use of the ART by the pregnant woman or using it for four weeks or less, with a consequent high viral load in the $3^{\text {rd }}$ trimester. The majority of pregnant women were diagnosed in time and started ART on time, i.e., at the beginning of the second trimester. Almost half of the pregnant women (42\%) had used ART since the first trimester, corresponding to those who had already been diagnosed with HIV infection and had been previously treated. This has possibly contributed to the good results found in this center.

The late diagnosis of HIV in pregnant women probably favored the absence of specific care necessary for MTCT prophylaxis, allowing the reflection on the expansion of educational and assistance actions covering the diagnosis of the disease and the importance of its treatment for the community.

The study ratifies the possibility of reducing the rates of vertical transmission, at the level of the goals proposed by WHO, when the recommendations of the Ministry of Health for the prophylaxis of MTCT are fulfilled. However, it is necessary to improve the records to ensure the continuity of care, enable the assessment of the quality of care provided, in addition to the fact that they are fundamental as a source of information for research and internal reorganization of the service.

The complexity of the inter-professional action required in these cases illustrates the importance of the commitment of the entire health team in the implementation of recommendations for the prophylaxis of MTCT and the search for safe and resolutive practices, in addition to the establishment of a co-participatory relationship and a dialogue with women to better adhere to the proposed recommendations.

\section{AUTHORS' CONTRIBUTIONS}

ANG, AJBT, DLMM and NCPR developed the study design and method; ANG, DLMM, NCPR, JTC, MBC and DFA evaluated the data and participated in the results elaboration; DLMM, NCPR, JTC and MBC analyzed the data; ANG, AJBT, DLMM, JTC, MAB and DFA wrote the manuscript; DLMM, AJBT, EFG and SRT edited and revised the manuscript. All authors read and approved the final edition of the manuscript.

\section{CONFLICT OF INTERESTS}

The authors have declared that no conflict of interests exist.

\section{FUNDING}

This study was supported by a grant from the Research Support Foundation of the State of Rio de Janeiro, FAPERJ, E-26/110.351/2012. The funders had no role in study design, data collection and analysis, decision to publish, or preparation of the manuscript.

\section{REFERENCES}

1. Luzuriaga K, Mofenson LM. Challenges in the elimination of pediatric HIV-1 infection. N Engl J Med. 2016;374:761-70

2. The Joint United Nations Programme on HIV/AIDS. UNAIDS 2016-2021 strategy: on the fast-track to end AIDS. Geneva: UNAIDS; 2020. [cited 2020 Aug 27]. Available from: https:// www.unaids.org/sites/default/files/media_asset/20151027_ UNAIDS_PCB37_15_18_EN_rev1.pdf

3. Rosa MC, Lobato RC, Gonçalves CV, Silva NM, Barral MF, Martinez AM, et al. Evaluation of factors associated with vertical HIV-1 transmission. J Pediatr (Rio J). 2015;91:523-8.

4. Brasil. Ministério da Saúde. Secretaria de Vigilância em Saúde. Departamento de DST, Aids e Hepatites Virais. Recomendações para profilaxia da transmissão vertical do HIV e terapia antirretroviral em gestantes. Brasília: Ministério da Saúde; 2010. [cited 2020 Aug 27]. Available from: http://www.aids.gov.br/pt-br/pub/2010/recomendacoespara-profilaxia-da-transmissao-vertical-do-hiv-e-terapiaantirretroviral-em

5. Brasil. Ministério da Saúde. Secretaria de Vigilância em Saúde. Departamento de Condições Crônicas e Infecções Sexualmente Transmissíveis. Indicadores e dados básicos do HIV/AIDS nos municípios brasileiros. [cited 2020 Aug 27]. Available from: http://indicadores.aids.gov.br/

6. Brasil. Ministério da Saúde. Recomendações para profilaxia da transmissão vertical do HIV e terapia anti-retroviral em gestantes. Brasília: Ministério da Saúde; 2003. [cited 2020 Aug 27]. Available from: http://bvsms.saude.gov.br/bvs/ publicacoes/gestante2.pdf

7. Brasil. Ministério da Saúde. Secretaria de Vigilância Sanitária. Programa Nacional de Controle e Prevenção de DST/ 
AIDS. Boletim epidemiológico de HIV/Aids 2019. Brasília: Ministério da Saúde; 2019. [cited 2020 Aug 27]. Available from: http://www.aids.gov.br/pt-br/pub/2019/boletimepidemiologico-de-hivaids-2019

8. Connor EM, Sperling RS, Gelber R, Kiselev P, Scott G, O'Sullivan $\mathrm{MJ}$, et al. Reduction of maternal-infant transmission of human immunodeficiency virus type 1 with zidovudine treatment. Pediatric AIDS Clinical Trials Group Protocol 076 Study Group. N Engl J Med. 1994;331:1173-80.

9. Mandelbrot L, Landreau-Mascaro A, Rekacewicz C, Berrebi A, Bénifla JL, Burgard M, et al. Lamivudine-zidovudine combination for prevention of maternal-infant transmission of HIV-1. JAMA. 2001;285:2083-93.

10. Brasil. Ministério da Saúde. Secretaria de Vigilância em Saúde. Programa Nacional de DST e Aids. Protocolo para a prevenção de transmissão vertical de HIV e sífilis: manual de bolso. Brasília: Ministério da Saúde; 2007.[cited 2020 Aug 27]. Available from: http://bvsms.saude.gov.br/bvs/publicacoes/ protocolo_prevencao_transmissao_verticalhivsifilis_ manualbolso.pdf

11. Jourdain G, Mary JY, Coeur SL, Ngo-Giang-Huong N, Yuthavisuthi P, Limtrakul A, et al. Risk factors for in utero or intrapartum mother-to-child transmission of human immunodeficiency virus type 1 in Thailand. J Infect Dis. 2007;196:1629-36.

12. Brasil. Ministério da Saúde. Secretaria de Vigilância em Saúde. Departamento de Doenças de Condições Crônicas e Infecções Sexualmente Transmissíveis. Protocolo clínico e diretrizes terapêuticas para prevenção da transmissão vertical de HIV, sífilis e hepatites virais. Brasília: Ministério da Saúde; 2019. [cited 2020 Aug 27]. Available from: http://www.aids.gov.br/ pt-br/pub/2015/protocolo-clinico-e-diretrizes-terapeuticaspara-prevencao-da-transmissao-vertical-de-hiv

13. Brasil. Ministério da Saúde. Secretaria de Vigilância em Saúde. Departamento de Vigilância, Prevenção e Controle das Infecções. Sexualmente Transmissíveis, do HIV/Aids e das Hepatites Virais. Protocolo clínico e diretrizes terapêuticas para manejo da infecção pelo HIV em crianças e adolescentes. Brasília: Ministério da Saúde; 2017. [cited 2020 Aug 27]. Available from: http://conitec.gov.br/images/Protocolos/ PCDT_criancaeadolescente_09_2017.pdf

14. Barbosa BL, Marques AK, Guimarães JV. Gestantes HIV positivas e os fatores de risco relacionados à transmissão vertical do HIV. Ver Enferm UFPE on line. 2018;12:171-8.

15. Brasil. Ministério da Saúde. Secretaria de Vigilância em Saúde. Departamento de DST, Aids e Hepatites Virais. Recomendações para terapia antirretroviral em crianças e adolescentes infectados pelo HIV 2009. Brasília: Ministério da Saúde; 2012. [cited 2020 Aug 27]. Available from: http:// bvsms.saude.gov.br/bvs/publicacoes/recomendacoes_ antiretroviral_criancas_hiv_2009_suplemento_2.pdf
16. Brasil. Ministério da Saúde. Secretaria de Vigilância em Saúde. Departamento de DST, Aids e Hepatites Virais. Protocolo clínico e Diretrizes terapêuticas para manejo da infecção pelo HIV em crianças e adolescentes. Brasília: Ministério da Saúde; 2014. [cited 2020 Aug 27]. Available from: http://www. aids.gov.br/pt-br/pub/2014/protocolo-clinico-e-diretrizesterapeuticas-para-manejo-da-infeccao-pelo-hiv-em-criancas-e

17. Brasil. Ministério da Saúde. Secretaria de Vigilância em Saúde. Departamento de Vigilância, Prevenção e Controle das Infecções Sexualmente Transmissíveis, do HIV/Aids e das Hepatites Virais. Protocolo clínico e diretrizes terapêuticas para manejo da infecção pelo HIV em crianças e adolescentes. Brasília: Ministério da Saúde; 2018. [cited 2020 Aug 27]. Available from: http://www.aids.gov.br/pt-br/pub/2017/ protocolo-clinico-e-diretrizes-terapeuticas-para-manejo-dainfeccao-pelo-hiv-em-criancas-e

18. Brandão MN, Souza ES, Brito RJ, Cavalcanti MM, Brandão MF, Cavalcante MC. Challenges in preventing vertical HIV transmission in Petrolina, Pernambuco and Juazeiro, Bahia. Rev Bras Saude Mater Infant. 2016;16:313-24.

19. Andrade SD, Sabidó M, Monteiro WM, Canellas L, Prazeres V, Benzaken AS. Mother-to-child transmission of HIV from 1999 to 2011 in the Amazonas, Brazil: risk factors and remaining gaps in prevention strategies. Pediatr Infect Dis J. 2016;35:189-95.

20. Barral MF, Oliveira GR, Lobato RC, Mendoza-Sassi RA, Martínez AM, Gonçalves CV. Risk factors of HIV-1 vertical transmission (VT) and the influence of antiretroviral therapy (ART) in pregnancy outcome. Rev Inst Med Trop Sao Paulo. 2014;56:133-8.

21. Melo VC, Maia MM, Correa Júnior MD, Kakehasi FM, Ferreira FG, de Andrade BA, et al. Vertical transmission of HIV-1 in the metropolitan area of Belo Horizonte, Brazil: 2006-2014. Rev Bras Ginecol Obstet. 2018;40:59-65.

22. Endalamaw A, Demsie A, Eshetie S, Habtewold TD. A systematic review and meta-analysis of vertical transmission route of HIV in Ethiopia. BMC Infect Dis. 2018;18:283.

23. Greco DB. Ética, saúde e pobreza: as doenças emergentes no século XXI. Bioetica. 1999;7:189-198.

24. Kalckmann S, Santos CG, Batista LE, Cruz VM. Racismo institucional: um desafio para a eqüidade no SUS? Saude Soc. 2007;16:146-55.

25. Cardoso AJ, Griep RH, Carvalho HB, Barros A, Silva SB, Remien RH. Infecção pelo HIV entre gestantes atendidas nos centros de testagem e aconselhamento em Aids. Rev Saude Publica. 2007;41 Suppl 2:101-8.

26. Fylkesnes K, Ndhlovu Z, Kasumba K, Musonda RM, Sichone M. Studyng dynamics of the HIV epidemic: population-based data compared with sentinel surveillance in Zambia. AIDS. 1998;12:1227-34.

27. Calleja JM, Walker N, Cuchi P, Lazzari S, Ghys PD, Zacarias F. Status of the HIV/AIDS epidemic and methods to monitor it 
in Latin America and Caribbean region. AIDS. 2002;16 Suppl 3:S3-12.

28. Hạnh NT, Gammeltoft TM, Rasch V. Number and timing of antenatal HIV testing: Evidence from a community-based study in Northern Vietnam. BMC Public Health. 2011:11;183.

29. Mor Z, Sheffer R, Chemtob D. Mother-to-child HIV transmissions in Israel, 1985-2011. Epidemiol. Infect. 2017;145:1913-21.

30. Rodrigues ST, Vaz MJ, Barros SM. Transmissão vertical do HIV em população atendida no serviço de referência. Acta Paul Enferm. 2013;26:158-64.

31. Lussiana C, Clemente SV, Ghelardi A, Lonardi M, Tarquino IA, Floridia M. Effectiveness of a prevention of mother-to-child HIV transmission programme in an urban hospital in Angola. PLoS One. 2012;7:e36381.
32. Yitayew YA, Bekele DM, Demissie BW, Menji ZA. Mother to child transmission of HIV and associated factors among HIV exposed infants at public health facilities, Dessie Town, Ethiopia. HIV AIDS (Auckl). 2019;11:343-50.

33. Arango-Ferreira C, Villegas DI, Burbano LD, Quevedo A. Calidad del seguimiento a la exposición perinatal al HIV y observancia de las estrategias reconocidas para disminuir su transmisión en un centro de referencia de Medellín. Biomedica. 2019;39 Suppl 2:66-77.

34. Moreno CC, Rea MF, Filipe EV. Mães HIV positivo e a nãoamamentação. Rev Bras Saude Mater Infant. 2006;6:199-208. 